\title{
Influence of Low Carbohydrate High Fat Ketogenic Diets on Renal and Liver Parameters
}

\author{
B. O. Eiya ${ }^{1}$, R. O. Aikpitanyi-iduitua ${ }^{1}$ \\ ${ }^{1}$ Department of Physiology, School of Basic Medical Sciences, College of Medical Sciences, University of Benin, \\ Benin \\ Correspondence: B. O. Eiya, Department of Physiology, School of Basic Medical Sciences, College of Medical \\ Sciences, University of Benin, Benin.
}

Received: March 30, 2020 Accepted: May 28, 2020 Online Published: July 2, 2020

doi:10.5539/ijc.v12n2p6

URL: https://doi.org/10.5539/ijc.v12n2p6

\begin{abstract}
In recent times the use of high fat ketogenic diet as a treatment strategy in some diseases and weight control has been on the increase. This study aims to elucidate the effect of high fat ketogenic diet on some renal and liver parameters. Forty albino rats were used and divided into four groups. Group A was control; B, C, and D were fed with diets including butter, coconut oil and olive oil respectively for eight weeks. Urine and serum samples were assayed spectrophotometrically. There was a significant difference in urinary albumin $(0.13 \pm 0.01 \mathrm{~g} / \mathrm{dl})$ of group $\mathrm{D}$ when compared with control $(0.22 \pm 0.03 \mathrm{~g} / \mathrm{dl})$. Urinary creatinine concentrations of group $\mathrm{D}(4.32 \pm 0.70 \mathrm{mg} / \mathrm{dl})$ was higher than group C $(1.75 \pm 0.46 \mathrm{mg} / \mathrm{dl})$. Urea of group B $(39.40 \pm 4.70 \mathrm{mg} / \mathrm{dl})$, group C $(29.90 \pm 1.46 \mathrm{mg} / \mathrm{dl})$ and group D $(40.20 \pm 2.62 \mathrm{mg} / \mathrm{dl})$ were lower than control group $(64.20 \pm 3.41 \mathrm{mg} / \mathrm{dl})$. Serum creatinine concentrations of group B $(1.05 \pm 0.09 \mathrm{mg} / \mathrm{dl})$, group $\mathrm{C}(0.85 \pm 0.07 \mathrm{lmg} / \mathrm{dl})$ and group $\mathrm{D}(1.03 \pm 0.07 \mathrm{mg} / \mathrm{dl})$ were reduced significantly. Albumin: creatinine ratio of group A (120.6 \pm 32.04$)$ was higher than that of group D $(41.31 \pm 8.28)$. AST $(260.1 \pm 17.80)$ was higher

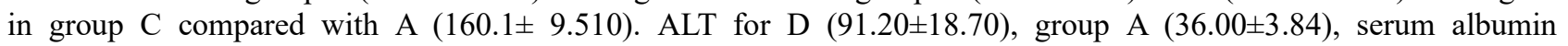

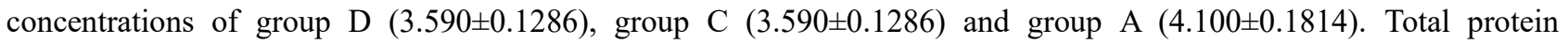

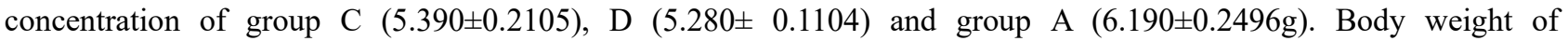
experimental groups reduced while the control groups increased. This study has confirmed that high fat ketogenic diet can be used for weight management however it could be harmful to the liver but did not show any harmful effects on the kidneys.
\end{abstract}

Keywords: high fat, ketogenic diet, kidney and liver

\section{Introduction}

The use of LCHF ketogenic diet dates back to over 90 years, when the diet was used in the treatment of refractory epilepsy (Wilder, 1921). The name ketogenic diet arose from the fact that intake of this diet resulted in the production of ketone bodies which serves as an alternative source of energy to the brain. In recent time, ketogenic diet have also been employed in weight management, this is based on the hypothesis that energy from the diet when used up for energy would result in calories waste, thus supporting weight loss (Feinman \& Fine,2007, Halton \& Hu 2004). Outside its use in weight control, the use of high fat ketogenic diet have been shown to be effective in type 11 diabetes mellitus management as well as in the management of renal impairment (Michal et al., 2011). Tonna et al., (2010) reported the ability of high fat ketogenic diet to reverse diabetic nephropathy. One hypothesis is that the use of energy from proteins in ketogenic diet is an expensive process for the body and so leads to a waste of calories, therefore increasing weight loss (Feinman and Fine,2007;Fine and Feinman,2004;Halton and Hu,2004) and it's a remedy for obesity, a major problem affecting up to $30 \%$ of the adult population (Kramer and Luke, 2007), with complications including type 2 diabetes mellitus and renal function impairment (Michal et al., 2011). Stereotypical results have proven that the numerical density of glomerulus and total number of glomeruli in rats fed the high fat ketogenic diet for a prolonged period of time was significantly decreased, indicating glomerular atrophy (Altakunak et al., 2008;). In another study, the ketogenic diet was proven to reverse diabetic nephropathy (Tonna et al., 2010) by producing prolonged exposure to the ketone 3-beta-hydroxybutyric acid (3-OHB), which blocks the inhibition of agouti-related peptide by glucose (Poplawski et al., 2011; Bailey et al., 2005). The diet reversed blood glucose to normal in akita mice (Susztak et al., 2006) as indicated by urinary albumin/creatinine ratios, and in patients with type 2 diabetes mellitus it greatly improved fasting glucose levels (Gannon and Nuttall, 2004) and increased insulin sensitivity (Samaha et al., 2003), thereby alleviating glycosuria and 
reversing kidney damage due to excessive glucose excretion. The ketogenic diet halted the progression of renal insufficiency in patients with chronic renal failure, as accessed by serial determination of creatinine levels.

Liver disease have in the past being linked to high consumption of alcohol resulting in alcoholic liver disease, in recent times, a new type of liver disease known as the nonalcoholic fatty liver disease (NAFLD) has been associated to unhealthy diet, resulting in gradual accumulation of fat in the liver. In fact; some school of thoughts feels that high carb diets and not high fat diets results in NAFLD. They attributed it to the synthesis of fat from de novo lipogenesis, (ie the liver creating fat from excess carbohydrate and protein).

There are controversies as to the impact of high fat ketogenic diet on liver functions, while some studies have reported that this diet can impact negatively on the kidney, others have reported otherwise. Arslan et al., (2016) observed high levels of Aspartate Transaminases (AST) \& Alanine Transaminases (ALT) after two months intake of the diet. Hepatic steatosis in both short- and long- term intake of the diet was observed in mice fed with this diet (Ellenbrok, 2014). In a meta- analysis study carried out by Fahimeh et al., (2014), they concluded that intake of LCD improves liver fat contents but not serum enzymes.

Information on the relationship between ketogenic diets and the type of fat used are limited, in ketogenic diet the consumption of both saturated and unsaturated fats is encouraged. The consumption of saturated fat is generally considered a risk factor for dyslipidemia, which in turn is a risk factor for some types of cardiovascular disease (Canon et al., 2006). Abnormal blood lipid levels, that is high in total cholesterol, high levels of triglycerides, high levels of low-density lipoprotein (bad cholesterol) or low levels of high density lipoprotein (Good cholesterol), are all associated with increased risk of heart disease and stroke. Many health authorities such as the America Diabetic Association (Kris-Etherton and Innis, 2007), the British Diabetic Association, America Heart Association (Sacks et al., 2017), the World Heart Federation, the British National Health Service, among others, advise that saturated fat is a risk factor for cardiovascular diseases. The World Health Organization in May 2015 recommends switching from saturated to unsaturated fats. A limited number of systematic reviews have examined the relationship between saturated fat and cardiovascular diseases and have come to different conclusions. A 2015 systematic review found no association between saturated fat consumption and risk of heart disease, stroke, diabetes, or death. There are no enough literatures on the effect of the type of fat used in the preparation of ketogenic diets on biochemical parameters, most of the available literatures emphasis more on the effects of the diet on biochemical parameters without looking at the nature of fat used in preparing the diet, it is therefore the aim of this study to look at the effect of three different fats type ketogenic diets and ascertain if the type of fats used in the preparation of the diet has any significant effect on liver and renal function of Wistar albino rats.

\section{Methods}

\subsection{Experimental Design}

Forty (40) albino Wistar rats of either sex were used for this study. They were weighed on arrival and acclimatized for two weeks. At the end of acclimatization, the rats were divided into four groups of 10 each; Group A (10) was the control group fed normal rat chow, while Group B (10), Group C (10), Group D (10) were experimental groups fed with $65 \%$ ketogenic diet made with butter, coconut oil and olive oil respectively. They were fed with these diets for a period of eight weeks ( 2 months) and were allowed free access to feeds and water during the duration of the experiment.

\subsection{Diet Formulation}

The experimental groups were fed $65 \%$ ketogenic diets made of butter, coconut oil and olive oil along with the other constituents of the diets for a period of eight (8) weeks, Percentage Composition of Experimental Diet

\begin{tabular}{l|l|l|l|l}
\hline CONSTITUENTS & $\begin{array}{l}\text { CONTROL } \\
(\mathrm{A})\end{array}$ & $\begin{array}{l}\text { EXPERIMENTAL } \\
\text { GROUP }(\mathrm{B})\end{array}$ & $\begin{array}{l}\text { EXPERIMENTAL } \\
\text { GROUP }(\mathrm{C})\end{array}$ & $\begin{array}{l}\text { EXPERIMENTAL } \\
\text { GROUP (D) }\end{array}$ \\
\hline COCONUT FLOUR & - & $15 \mathrm{~g}$ & $15 \mathrm{~g}$ & $15 \mathrm{~g}$ \\
\hline MAIZE & $70 \mathrm{~g}$ & - & - & - \\
\hline PALM OIL & $10 \mathrm{~g}$ & - & - & - \\
\hline BUTTER & - & $65 \mathrm{~g}$ & - & - \\
\hline COCONUT OIL & - & - & $65 \mathrm{~g}$ & - \\
\hline OLIVE OIL & - & - & - & $65 \mathrm{~g}$ \\
\hline FISH MEAL & $15 \mathrm{~g}$ & $15 \mathrm{~g}$ & $15 \mathrm{~g}$ & $15 \mathrm{~g}$ \\
\hline BONE MEAL & $2 \mathrm{~g}$ & $2 \mathrm{~g}$ & $2 \mathrm{~g}$ & $2 \mathrm{~g}$ \\
\hline LIMESTONE & $1 \mathrm{~g}$ & $1 \mathrm{~g}$ & $1 \mathrm{~g}$ & $1 \mathrm{~g}$ \\
\hline SALT & $0.5 \mathrm{~g}$ & $0.5 \mathrm{~g}$ & $0.5 \mathrm{~g}$ & $0.5 \mathrm{~g}$ \\
\hline VIT-MIN PREMIX & $0.5 \mathrm{~g}$ & $0.5 \mathrm{~g}$ & $0.5 \mathrm{~g}$ & $0,5 \mathrm{~g}$ \\
\hline LYSINE & $0.3 \mathrm{~g}$ & $0.3 \mathrm{~g}$ & $0.3 \mathrm{~g}$ & $0.3 \mathrm{~g}$ \\
\hline MET \& CYS & $0.3 \mathrm{~g}$ & $0.3 \mathrm{~g}$ & $0.3 \mathrm{~g}$ & $0.3 \mathrm{~g}$ \\
\hline
\end{tabular}




\subsection{Collection of Samples}

After two weeks of feeding the rats with the diets, 24-hour urine samples were collected using metabolic cages and the rats were ascertained to be in ketosis using a urinalysis test strip. At the end of two months they were weighed and put in metabolic cages, 24-hour urine samples were again collected into universal containers. The rats were put to sleep using chloroform in a closed chamber and fasted blood samples were collected from the abdominal aorta and then the heart into plain test tubes. The blood was allowed to clot and the clot was dislodged, spun on a centrifuge to get the serum which was used for the analysis.

\subsection{Determination of Biochemical Parameters}

Creatinine: This was assayed by two-point's kinetic-using the modified Jaffe increasing reaction proposed by Bartels and Bolumer (1972). Serum urea was determined by Berthelot method (Newman and Price, 1999). Urinary microalbumin was determined by method described by feldi-Rasmussen et al., (1985). Aspartate amino transferase and Alanine amino transferase were estimated using the Colorimetric Method of Reithman and Frankel (1975).

\subsection{Statistical Analysis}

Data is presented in mean \pm standard error of mean (SEM). Analysis of variance (ANOVA) was used to compare in between groups, while turkey test was considered the post-hoc test. $\mathrm{P} \leq 0.05$ was considered as the statistical significance.

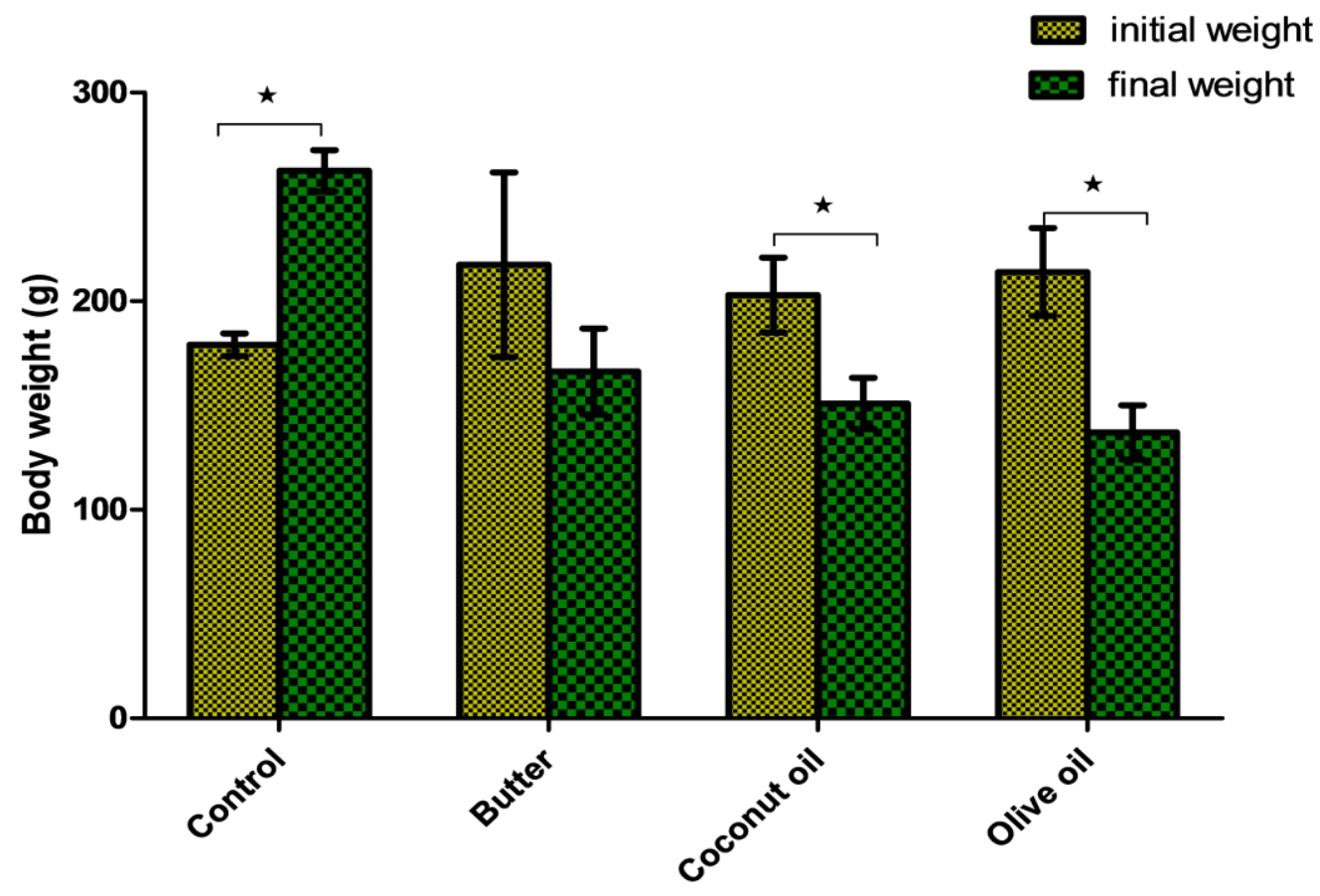

Figure 1. Effect of different ketogenic diet made of butter, coconut oil, and olive oil on the rat body weight

\section{Results}

Table 1. mean values of urine and blood renal parameters in rats fed with $65 \%$ high fats ketogenic diets

\begin{tabular}{l|l|l|l|l}
\hline Parameters & Control & Butter & Coconut oil & Olive oil \\
\hline Urine albumin $(\mathrm{g} / \mathrm{dl})$ & $0.22 \pm 0.03$ & $0.19 \pm 0.02$ & $0.15 \pm 0.02$ & $0.13 \pm 0.01^{* \mathrm{a}}$ \\
\hline Urine creatinine $(\mathrm{mg} / \mathrm{dl})$ & $3.84 \pm 1.02$ & $3.84 \pm 0.90$ & $1.75 \pm 0.46$ & $4.31 \pm 0.70^{\mathrm{b}}$ \\
\hline Serum urea $(\mathrm{g} / \mathrm{dl})$ & $64.20 \pm 3.41$ & $39.40 \pm 4.70^{*}$ & $29.90 \pm 1.46^{*}$ & $40.20 \pm 2.62^{* \mathrm{~b}}$ \\
\hline Serum creatinine $(\mathrm{mg} / \mathrm{dl})$ & $1.42 \pm 0.04$ & $1.05 \pm 0.09^{*}$ & $0.85 \pm 0.07^{*}$ & $1.03 \pm 0.07^{*}$ \\
\hline Albumin-creatinine ratio & $120.6 \pm 32.04$ & $94.64 \pm 23.03$ & $174.7 \pm 61.82$ & $41.31 \pm 8.28^{* a b}$ \\
\hline
\end{tabular}

$* \mathrm{P} \leq 0.05$ indicates significant difference at the different diets compared with the control.

aP $\leq 0.05$ indicates significant difference when coconut oil or olive oil ketogenic fed rats are compared with butter ketogenic fed rats.

${ }^{\mathrm{b}} \mathrm{P} \leq 0.05$ indicates significant difference when coconut oil ketogenic fed rats are compared with olive oil ketogenic fed rats 
Table 2. Mean values of some liver functions markers of rats fed with $65 \%$ high fats ketogenic diets

\begin{tabular}{l|l|l|l|l}
\hline Parameters & Control & Butter & Olive Oil & Coconut Oil \\
\hline AST (U/I) & $160.1 \pm 9.510$ & $143.4 \pm 8.218$ & $196.1 \pm 3.926$ & $260.1 \pm 17.80^{*}$ \\
\hline ALP (U/I) & $9.900 \pm 0.7371$ & $24.90 \pm 2.536^{*}$ & $23.00 \pm 2.591^{*}$ & $21.80 \pm 3.422^{*}$ \\
\hline ALT (U/I) & $36.00 \pm 3.884$ & $40.10 \pm 2.173$ & $50.30 \pm 2.996$ & $91.20 \pm 18.70^{*}$ \\
\hline ALBUMIN (g/dl) & $4.100 \pm 0.1814$ & $3.590 \pm 0.1286^{*}$ & $3.300 \pm 0.1085^{*}$ & $3.390 \pm 0.0862^{*}$ \\
\hline GLOBULIN(g/dl) & $2.160 \pm 0.1097$ & $1.870 \pm 0.1193$ & $2.180 \pm 0.08138$ & $1.960 \pm 0.1352$ \\
\hline $\begin{array}{l}\text { TOTAL PROTEIN } \\
(\mathrm{g} / \mathrm{dl})\end{array}$ & $6.190 \pm 0.2496$ & $5.320 \pm 0.12818^{*}$ & $5.390 \pm 0.2105^{*}$ & $5.280 \pm 0.1104^{*}$ \\
\hline
\end{tabular}

$* \mathrm{P}<0.05$ indicates significant difference between groups

\section{Discussion}

In this current study, we looked at the effect of three fat (coconut oil, olive oil and butter) types' ketogenic diets on liver and renal parameters in wistar rats for a period of two months. We observed a significant increase in AST and ALT levels only in coconut oil based diet when compared with control, while there was a significant increase in ALP levels of all three ketogenic diets (olive oil, butter and coconut oil), when compared with control. Albumin levels were also significantly reduced in the ketogenic fed groups when compared with control, there was however no significant change in globulin levels, total protein levels reduced significantly only in the olive oil and coconut oil based diets. Previous studies have shown that intake of ketogenic diet have long and short term effects, dyslipidemia, kidney stones, carnithine deficiency are some of the long term effects (Cervenka et al., 2016). Kang et al., (2004) and Arslan et.al (2016), have reported an alteration in serum levels of liver enzymes following intake of ketogenic diet, Arslan et al., in their study observed an increase in ALT and AST in 2 out of every 3 rats after intake of ketogenic diet, their findings is similar to our observation in this current study as AST and ALT levels of rats in this study increased significantly when compared with control. In another study by Henrietta and Olumese (2010), they reported increased levels of AST and ALT in rats fed ketogenic diet, this is also in agreement with our findings, where we observed significant increase in ALP in all the ketogenic fed groups while AST and ALT increased only in rats fed the coconut based diet. ALP is a sensitive detector for early intra hepatic and extra hepatic bile obstruction, the presence of infiltrative disease of the liver and all bone diseases associated with osteoblastic activities, (Friedman et al., 2003). Albumin levels significantly decreased in ketogenic groups compared with control, the liver is the only site for albumin synthesis hence anything that affect the liver will affect its synthesis (Marjolain et al., 2008). This finding also is in agreement with that of Henrietta and Olumese (2010), but disagree with the observations of Imafidon and Okunrobo, (2012), who reported a significant increase in levels of albumin and total protein after intake of ketogenic diet. The varying effects the different diets have on the various parameters can be attributed to the fact that different types of fats were used to constitute the diets and since they contain different fatty acids making some more ketogenic than others. Coconut oil is a medium chain fatty acid which contains $50 \%$ of Lauric acid which easily enters the mitochondria independently of carnithine transport system and therefore easily transfers into the mitochondria. One mechanism that has been attributed to liver disease is depletion of carnitine, an amino acid derivative that is responsible for the transport of long chain fatty acids (LCFA) to the mitochondria (Lheureux, \& Hantson, 2009). The fact that coconut oil bypasses the carnitine pathway thus getting to the mitochondria faster than the other fatty acids could be responsible for its fast effects observed in this study.

Findings from this study did not show any significant increase in renal parameters in rats fed with ketogenic diets, rather the diets were observed to improve renal parameters (serum creatinine, urinary albumin and urea) when compared with control. However, when the different ketogenic diets (KD) (butter, coconut oil and olive oil) were compared between each other, there were significant differences between groups but the values were within the control values. These results have further buttressed the fact that high fat ketogenic diet does not affect the kidney as seen in the creatinine and urinary albumin values which were lower in the ketogenic groups when compared with control (Allen 2002). This is in agreement with reports of researchers from Mount Sinai School of Medicine who observed in their study that intake of high fat ketogenic diet could reverse impaired kidney function in type $1 \& 2$ diabetic subjects. In their study they reported the reversed expression of genes associated with diabetic related kidney failure after 8 weeks intake of KD in mice, this is similar to findings in our study as rats fed KD diet were seen to have improved renal parameters when compared with control. Chikako et al, (2016), further confirmed this in their study where they looked at the effect of LCD on renal parameters in over weight obese individuals without chronic kidney disease and their result showed that eGFR was greater in LCD fed individuals compared with control diet. The various ketogenic diet also resulted in weight loss when initial weight of the rats were compared with the final weight after eight weeks intake 
of the diet as compared to the control rats that gained weight. This is in agreement with our previous studies, (Eiya \& Osakue, 2019, 2018), it also agrees with the findings of Feinman and Fine (2004). The reduction in weight can be attributed to reduced caloric intake and the rats burning fat as an alternative source of fuel to glucose (Westerterp-Platenga et al., 2009; Seyfried \& Murkherjee, 2005). When compared in between groups, there was significant reduction in weight in groups fed olive oil and coconut oil, compared with the group fed butter.

\section{Conclusion}

This study has again confirmed that high fat ketogenic diet can be used for weight management however intake of LCHF diet could be harmful to the liver due to its effect on transaminases and serum albumin, it has also shown that the type of fat used in constituting the diet can contribute to the level of damage the diet can cause to the liver as observed in rats fed with the coconut oil based diet. The diet did not have any harmful effect on the kidney rather it was observed to improve renal function as was shown by the reduction of serum creatinine, urea and urinary albumin levels. The need for further studies to ascertain the best fat type that will be used in the preparation of HFLC diet is very important; this will no doubt ensure the benefit of this diet is optimized.

\section{References}

Allen S. (2002). The liver: Anatomy, Physiology, Disease and Treatment. North Eastern University Press, USA, 50(2), 310-314.

Altunkaynak, M. E., Özbek, E., Altunkaynak, B. Z., Can, I., Unal, D., \& Unal, B. (2008). The effects of high-fat diet on the renal structure and morphometric parametric of kidneys in rats. Journal of Anatomy, 6(212), 845-852. https://doi.org/10.1111/j.1469-7580.2008.00902.x

Arslan, N., Guzel, O., Kose, E., Yilmaz, U., Kuyum, P., \& Aksoy, B. (2016). Is ketogenicdiet treatment hepatoxic for children with intractable epilepsy? Seizure, 43, 32-38. https://doi.org/10.1016/j.seizure.2016.10.024

Bailey, E. E., Pfeifer, H. H., \& Thiele, E. A. (2005). The use of diet in the treatment of epilepsy. Epilepsy Behav., 6, 4-8. https://doi.org/10.1016/j.yebeh.2004.10.006

Bartels, H., \& Bolumer, M. (1972). Serum creatinine determination without protein precipitation. Clin Chem Acta, 37, 193-197. https://doi.org/10.1016/0009-8981(72)90432-9

Cannon, C. P. et al., (2006). Metal analysis of cardiovascular outcomes trials coparing intensive versus moderate statin therapy. Journal of the American College of Cardiology, 48(3), 438-445. https://doi.org/10.1016/j.jacc.2006.04.070

Cervenaka, M. C., Henry, B. J., Kossoff, E. H., \& Zahava, T. R. (2016). The ketogenic and modified atkins diets: treatments foe epilepsy and other disorders. Springer Publishing Company, 376.

Chikako, O., Yoshitaka, H., Takuya, F., Muhei, T., Mai, A., \& Masahiro, Y. (2016). Impact of Low-carbohydrate diet on renal function: a meta-analysis of over 1000 individuals from nine randomized controlled trials. British Journal of Nutrition, 116, 632-638. https://doi.org/10.1017/S0007114516002178

Eiya, B. O., \& Osakue, J. (2019). Effects of high fat ketogenic diet on some cardiovascular and renal parameters in wistar albino rats. International Journal of Biological and Chemical Sciences, 12(6), 2703. https://doi.org/10.4314/ijbcs.v12i6.19

Ellenbroek, J., VanDijck, L., Töns, H., Rabelink, T., Carlotti, F., Ballieux, B., \& Koning, E. (2014). Long-term ketogenic diet causes glucose intolerance and reduced $\beta$-and $\alpha$-cell mass but no weight loss in mice. American Journal Physiology of Endocrinological Metabolism, 306(5), 552-558. https://doi.org/10.1152/ajpendo.00453.2013

Feinman, R. D., \& Fine, E. J. (2007). Non equilibrium thermodynamics and energy efficiency in weight loss diets. Theol. Biol. Med. Model, 4, 27. https://doi.org/10.1186/1742-4682-4-27

Feldi-Rasmussen, B., Deckert, M., \& Dinesen, B. (1985). Enzyme immunoassay: an improved determination of urinary albumin in diabetics with incipient nephropathy. Seand. J. Clin. Lab. Invest., 45, 539-544. https://doi.org/10.3109/00365518509155256

Fine, E. J., \& Feinman, R. D. (2004). Thermodynamics of weight loss diets. Nutr. Metab. (Lond)., $1,15$. https://doi.org/10.1186/1743-7075-1-15

Friedman, S., Martin, P., \& Munoz (2003). Laboratory evaluation of the patient with liver disease. Hepatology, a Textbook of Liver Disease, 1, 661-709.

Gannon, M. C., \& Nuttall, F. Q. (2004). Effect of a high-protein, low-carbohydrate diet on blood glucose control in people with type 2 diabetes. Diabetes, 53, 2375-2382. https://doi.org/10.2337/diabetes.53.9.2375

Halton, T. L., \& Hu, F. B. (2004). The effects of high protein diets on thermogenesis, satiety and weight loss: a critical 
review. J. Am. Col. Nutr., 23, 373-385. https://doi.org/10.1080/07315724.2004.10719381

Henrietta, O., \& Fidelis, O. (2010). Effects of Low Carbohydrate High Fat Nigerian-Like Diet on Biochemical Indices in Rabbits. Pakistan Journal of Nutrition, 9(3), 640-644. https://doi.org/10.3923/pjn.2010.245.249

Imofidon, K., \& Okunrobo, L. (2012). Study on biochemical indices of liver function tests of albino rats supplemented with three sources of vegetable oils. Nigerian Journal of Basic and Applied Science, 19(2), 105-110.

Kang, H. C., Chung, D. E., Kim, D. W., \& Kim, H. D. (2004). Early and late onset complications of ketogenic diet for intractable epilepsy. Epilepsia, 45(9), 1116-1123. https://doi.org/10.1111/j.0013-9580.2004.10004.x

Kramer, H., Luke, A., \& Bidani, A. (2005). Obsity and prevalent and incident CKD: the hypertension detection and follow up program.AM J Kidney Dis., 46, 587-594. https://doi.org/10.1053/j.ajkd.2005.06.007

Kris-Etherton, P. M., Innis, S., \& American Dietc Association, Dietitians of Canada (2007). Position of the American Dietetic Association and Dietitians of Canada: Dietary Fatty Acids. Journal of the American Dietetic Association, 107(9), 1599-1611. https://doi.org/10.1016/j.jada.2007.07.024

Lheureux, P. E., \& Hantson, P. (2009). Carnitine in the treatment of valproic acid- induced toxicity. Clin. Toxicol. (Phila), 47(2), 101-111. https://doi.org/10.1080/15563650902752376

Marjolaine, R., Philippe, R., Nihar, R., Evelyne, T., \& Emmanuel, B. (2008). The antioxidant properties of serum albumin. Flebs Letters, 582(13), 1783-1787. https://doi.org/10.1016/j.febslet.2008.04.057

Michal, M., Poplawski, J. W., Mastaitis, F. I., Fabrizio, G., Feng, Z., \& Charles, V. M. (2011). Reversal of Diabetic Nephropathy by a Ketogenic Diet. PLoS ONE, 6(4), e18604. https://doi.org/10.1371/journal.pone.0018604

Newman, D. J., \& Price, C. P. (1999). Renal function and nitrogen metabolism, 3rd ed. Philadelphia. CA Burtis, ER Ashwood (EDS). Tietz: Textbook of clinical chemistry. WB Saunders. 1204-1264.

Poplawski, M. M., Mastaitis, J. W., Isoda, F., Grosjean, F., Zheng, C., \& Mobbs, V. (2011). Reversal of diabetic nephropathy by a ketogenic diet. PLoS ONE, 6(4). https://doi.org/10.1371/journal.pone.0018604

Reithman, S., \& Frankel, S. (1957). A colorimetric method for the determination of serum Oxaloacetic and glutamine acetic transaminases. American Journal of Clinical Pathology, 28(1), 56-63. https://doi.org/10.1093/ajcp/28.1.56

Sacks, F. M., Lichtenstein, A. H., Wu, J. H. Y., Appel, L. J., Creager, M. A., Kris-Etherton, P. M., ...Van Horn, L. V. (2017). Dietary Fats and Cardiovascular Disease: a Presidential Advisory from the American Heart Association. Circulation, 136, e1-e23. https://doi.org/10.1161/CIR.00000000000000510

Samaha, F. F., Iqbal, N., \& Seshadri, P. (2003). A low-carbohydrate as compared with a low-fat diet in severe obesity. $N$. Engl. J. Med., 348, 20774-2081. https://doi.org/10.1056/NEJMoa022637

Seyfried, T. N., \& Mukherjee, P. (2005). Targeting energy metabolism in brain cancer: Review and hypothesis. Nutr. Metab., 2, 1743-7075. https://doi.org/10.1186/1743-7075-2-30

Susztak, K., Raff, A. C., Schiffer, M., \& Bottinger, E. P. (2006). Glucose-induced reactive oxygen species cause apoptosis of podocytes and podocyte depletion at the onset of diabetic nephropathy. Diabetes, 55, 225-233. https://doi.org/10.2337/diabetes.55.01.06.db05-0894

Tonna, S., El-Osta, A., Cooper, M. E., \& Tikellis, C. (2010). Metabolic memory and diabetic nephropathy: potential role for epigenetic mechanisms. Nat Rev Nephrol., 6, 332-341. https://doi.org/10.1038/nrneph.2010.55

Westerterp-Plantenga, M. S., Nieuwenhuizen, A., Tome, D., Soenen, S., \& Westerterp, K. R. (2009). Dietary protein, weight loss, and weight maintenance. Annu Rev Nutr., 29, 21-41. https://doi.org/10.1146/annurev-nutr-080508-141056

Wilder, R. M. (1921). The effects of ketonemia on the course of epilepsy. Mayo clin proc., 2, 307-308.

\section{Copyrights}

Copyright for this article is retained by the author(s), with first publication rights granted to the journal.

This is an open-access article distributed under the terms and conditions of the Creative Commons Attribution license (http://creativecommons.org/licenses/by/4.0/). 